\title{
ANALISIS FAKTOR-FAKTOR YANG MEMPENGARUHI EFEKTIVITAS PELATIHAN PERIKANAN BUDIDAYA (Studi Kasus di Wilayah Kerja Balai Diklat Perikanan Banyuwangi)
}

\author{
Madyunin \\ Mahasiswa Pasca Sarjana Fakultas Perikanan dan Ilmu Kelautan \\ Universitas Brawijaya Malang \\ Email: masyunin@rocketmail.com
}

Diterima 30 Mei 2012 - Disetujui 3 Desember 2012

\begin{abstract}
ABSTRAK
Untuk mengejar ketertinggalan teknologi budidaya perikanan yang dialami oleh pembudidaya ikan saat ini, salah satu solusi yang dapat dilakukan yaitu melalui pelatihan perikanan budidaya. Penelitian analisis faktor-faktor yang mempengaruhi efektivitas pelatihan budidaya perikanan ini bertujuan untuk mengukur hubungan kausalitas dari faktor sarana pelatihan, kualitas peserta pelatihan, ketepatan metode pelatihan, kualitas bahan ajar, dan faktor kualitas pelatih terhadap efektivitas pelatihan budidaya perikanan. Obyek penelitian ini yaitu purnawidya pelatihan budidaya perikanan yang dilatih di Balai Diklat Perikanan Banyuwangi, yang tersebar di tiga provinsi, sebanyak 105 orang. Data dianalisis dengan Structural Equation Modeling (SEM). Hasil penelitian mengemukakan bahwa faktor sarana pelatihan berpengaruh positif signifikan terhadap efektivitas pelatihan budidaya perikanan dan efektivitas pelatihan budidaya perikanan terhadap efisiensi kinerja pembudidaya ikan berpengaruh positif signifikan. Selanjutnya diperoleh hasil bahwa faktor kualitas peserta pelatihan, kualitas isi bahan ajar, ketepatan metode pelatihan dan kualitas pelatih tidak signifikan terhadap efektivitas pelatihan yang dilakukan. Hasil penelitian merekomendasikan bahwa Balai Diklat Perikanan Banyuwangi perlu pembenahan terhadap kriteria calon peserta pelatihan, kualitas bahan pembelajaran, peningkatan kualitas pelatih.
\end{abstract}

Kata Kunci : efektivitas pelatihan, Structural Equation Modeling (SEM)

\section{Abstract: Analysis of Factors Affecting Effectiveness of Aquaculture Training (Case Study on the Fisheries Training Center of Banyuwangi). By: Madyunin.}

One of the solutions to pursue the lack of the aquaculture technology is providing a training program for fish farmer.This research was used using the Analysis of factors affecting the training effectiveness. Objective of the research were to measure the causality relations of the training equipment factor, the quality of the participants and the material, the provision of the training methods, and the quality of the trainers toward the effectiveness of training program. Object of the research was the Purnawidya of aquaculture training in the Banyuwangi Training Center which spread out in 3 provinces with over 105 participated. Data were analyzed by using the Structural Equation Modeling (SEM). Results shows that equipments have a positive significant impact toward the effectiveness of the training and the efficiency of the aquaculture performance. The quality of the training and the material, the methods, and the quality of the trainers not significant impacted the of effectiveness of the training program. The result recommends the Banyuwangi Training Center need to improve the criteria for selecting the participants, the quality of the materials, and to improve the quality of the trainers.

Keywords: effectiveness training, Structural Equation Modeling (SEM) 


\section{PENDAHULUAN}

Percepatan perubahan teknologi di bidang budidaya perikanan mampu meningkatkan produktifitas budidaya perikanan, tetapi dalam waktu yang bersamaan perepatan perubahan teknologi ini menyebabkan tertinggalnya pengetahuan dan keterampilan serta sikap dari masyarakat pembudidaya ikan tertinggal oleh kemajuan teknologi tersebut. Oleh karena itu, salah satu solusi untuk memecahkan masalah tersebut adalah melalui program pelatihan budidaya perikanan.

Balai Pendidikan dan Pelatihan Perikanan (BPPP) Banyuwangi sebagai salah satu UPT Badan Pengembangan Sumberdaya Manusia Kelautan dan Perikanan (BPSDM-KP), memiliki wilayah kerja meliputi lima provinsi yaitu Provinsi Jawa Timur, Bali, Nusa Tenggara Barat, Nusa Tenggara Timur dan Kalimantan Selatan. Dengan melibatakan 84 Kabupaten dan Kota di lima provinsi tersebut. Berikut ini merupakan data jumlah peserta pendidikan dan pelatihan BPPP Banyuwangi.

Tabel 1. Jumlah Peserta Pendidikan dan Pelatihan di BPPP Banyuwangi tahun 2006 sampai tahun 2010.

Table 1. The Number of Participants Education and Training in BPPP Banyuwangi 2006 Until 2010.

\begin{tabular}{ccc}
\hline No & $\begin{array}{c}\text { Tahun/ } \\
\text { Year }\end{array}$ & $\begin{array}{c}\text { Jumlah Peserta } \\
\text { Pelatihan/ } \\
\text { The Number of } \\
\text { Participants }\end{array}$ \\
\hline 1 & 2006 & 918 \\
2 & 2007 & 1026 \\
3 & 2008 & 468 \\
4 & 2009 & 1048 \\
5 & 2010 & 1307 \\
\hline & Jumlah/Total & 4767 \\
\hline
\end{tabular}

Sumber: BPPP Banyuwangi 2011/

Sources : BPPP Banyuwangi 2011

Data jumlah peserta pendidikan dan pelatihan perikanan yang terlihat dalam Tabel 1 menunjukkan kecenderungan kenaikan jumlah peserta pendidikan dan pelatihan. Pelatihan yang di selenggarakan BPPP Banyuwangi terdiri dari beberapa macam , yaitu perikanan tangkap, kepelautan, mesin perikanan, teknologi pengolahan hasil perikanan, sosial ekonomi perikanan dan perikanan budidaya. Dari jumlah peserta 4.767 orang selama lima tahun, jumlah peserta pelatihan teknis budidaya perikanan sebanyak 609 orang yang terdiri dari 90 orang petugas Dinas Kelautan dan Perikanan dan 519 orang merupakan tenaga pembudidaya perikanan dengan sistem tradisional plus untuk komoditas patin dan bandeng dan sistim intensif untuk komoditas lele.

Dengan meningkatnya jumlah peserta pelatihan, maka diharapkan produktifitas kinerja dari pembudidaya perikanan juga akan mengalami kenaikan, hal ini dikarenakan semakin meningkatnya kuantitas dan kualitas pengetahuan, keterampilan dan sikap yang dimiliki tenaga pembudidaya. Untuk itu perlu dikaji tentang faktor-faktor yang mempengaruhi efektivitas pelatihan budidaya perikanan.

Tujuan penelitian ini yaitu untuk mengukur hubungan kausalitas dari faktor penggunaan sarana atau media pelatihan terhadap efektivitas pelatihan budidaya perikanan, mengukur hubungan kausalitas dari faktor kualitas peserta pelatihan terhadap efektivitas pelatihan budidaya perikanan, mengukur hubungan kausalitas dari faktor kualitas isi bahan ajar pelatihan terhadap efektivitas pelatihan budidaya perikanan, mengukur hubungan kausalitas dari faktor ketepatan metode pelatihan terhadap efektivitas pelatihan budidaya perikanan, mengukur hubungan kausalitas dari faktor kualitas pelatih terhadap efektivitas pelatihan budidaya perikanan dan mengukur hubungan kausalitas efektivitas pelatihan budidaya perikanan terhadap efisiensi kinerja pembudidaya perikanan.

\section{METODOLOGI}

\section{Desain Penelitian}

Desain penelitian ini termasuk dalam desain penelitian kausal (Waluyo, 2011) yang berkaitan dengan hubungan sebab akibat, 
sehingga langkah-langkah yang dilakukan dalam penelitian kausal yaitu mengidentifikasi hubungan sebab akibat antar variabel, mencari tipe sesunguhnya dari fakta untuk membantu memahami dan memprediksi hubungan, menetapkan pendekatan kausal dari kejadiankejadian yang berurutan dan mengukur variasi antara penyebab yang diduga dan akibat yang diduga.

\section{Sumber Data}

Data primer didapat dari daftar pertanyaan/kuesioner yang diberikan kepada responden dan informasi tambahan didapatkan dari BPPP Banyuwangi, Dinas Perikanan dan Kelautan terkait dan pelatih yang telah memiliki pengalaman melalui wawancara langsung. Pada penelitian ini ada 37 indikator yang menjadi data primer yang terdiri atas, sarana/media pelatihan (4 indikator), kualitas peserta pelatihan budidaya perikanan (10 indikator), kualitas bahan ajar (4 indikator), ketepatan metode pelatihan budidaya perikanan (3 indikator), kualitas pelatih ( 3 indikator), efektivitas pelatihan budidaya perikanan (3 indikator), dan efisiensi kinerja pembudidaya ikan (10 indikator). Data ini diperoleh langsung dari responden yaitu pembudidaya ikan dan merupakan purnawidya dari pelatihan budidaya perikanan.

\section{Populasi dan Sampel}

Metode pengambilan sampel dalam penelitian ini ditentukan melalui proportional purposif sampling (Sugiono, 2002). Jumlah responden sesuai metode Structure Equation Modeling (Waluyo, 2011) adalah 5 -10 kali jumlah variabel pengamatan atau 100 - 200 sampel. Dengan mengacu pada pendapat tersebut maka jumlah sampel dalam penelitian ini adalah 105 responden.

\section{Metode Pengumpulan Data}

Metode pengumpulan data yaitu metode angket (kuesioner terstruktur) yang diberikan kepada responden. Pertanyaan disajikan dalam kuisioner berupa pertanyaan tertutup, dibuat dengan skala interval, sehingga jika diolah menunjukkan pengaruh atau hubungan antara variabel. Skala interval yang digunakan dalam penelitian ini yaitu bipolar adjective (Waluyo, 2011). Skala yang digunakan pada rentang interval 1-6.

\section{Teknik Analisis}

Analisis data secara kualitatif bertujuan untuk membahas dan menerangkan hasil penelitian, berbagai gejala atau kasus yang dapat diuraikan dengan menggunakan keterangan-keterangan yang tidak dapat diukur dengan angka-angka tetapi memerlukan penjabaran uraian yang jelas (Sugiyono, 2000).

Analisis data secara kuantitatif dilakukan menggunakan metoda analisis Structural Equation Model (SEM) dari software AMOS yang digunakan untuk menguji H1 (Sarana ( Media Pelatihan Budidaya Perikanan), H2 (Kualitas Peserta Pelatihan Budidaya Perikanan), H3 (Kualitas Isi Modul Pelatihan), H4 (Ketepatan Metode Pelatihan), H5 (Kualitas Pelatih) dan H6 (Efektivitas Pelatihan Budidaya Perikanan). Model kausal AMOS menunjukkan pengukuran dan masalah yang struktural dan digunakan untuk menganalisis dan menguji model hipotesis.

\section{HASIL DAN PEMBAHASAN}

\section{Indikator Ketepatan Sarana Dan Media Pelatihan}

Proses pelatihan teknis budidaya perikanan yang dilakukan di Balai Diklat Perikanan Banyuwangi dimulai dari Analisis Kebutuhan Diklat (AKD) budidaya perikanan, penyusunan kurikulum Diklat sesuai dengan kebutuhan calon peserta pelatihan berdasarkan hasil (AKD), pelaksanaan pelatihan budidaya perikanan dan berakhir dengan kegiatan evaluasi pasca Diklat. Adapun data hasil penelitian terhadap 105 responden selengkapnya yaitu seperti tertera dalam Tabel 2. 
Tabel 2. Frekuensi Jawaban Responden Dalam Menjawab Indikator Ketepatan Sarana dan Media Pelatihan.

Table 2. Frequency of Respondent's Answer in Answering Indicator Accuracy Means and Media Training.

\section{Indikator Ketepatan Sarana/Media Pelatihan/Means Accuracy Indicator/Media of Training}

\begin{tabular}{cccccc}
\multicolumn{5}{c}{ Frekuensi Jawaban Responden/ } \\
Frequency of Respondent's & Answer \\
\hline 1 & 2 & 3 & 4 & 5 & 6 \\
\hline
\end{tabular}

Jumlah kecukupan sarana/media digunakan dalam pelatihan/Numbers of means adequacy/media of training

$\begin{array}{llllll}1 & 13 & 17 & 28 & 22 & 24\end{array}$

Kualitas sarana/ media digunakan dalam pelatihan/ Means quality/media of training

$\begin{array}{llllll}1 & 2 & 33 & 42 & 27 & 28\end{array}$

Kesiapan sarana/ media digunakan dalam pelatihan/ Readines of means/media of training

$\begin{array}{llllll}0 & 0 & 4 & 19 & 38 & 34\end{array}$

Kesesuaian sarana media /digunakan dalam pelatihan/ Means of Training suitability

$\begin{array}{llllll}0 & 0 & 0 & 16 & 53 & 36\end{array}$

\section{Indikator Kualitas Peserta Pelatihan Budidaya Perikanan/Participant Quality Indicator of Aquaculture Training}

Tingkat pendidikan makin tinggi, semakin efektif mengikuti pelatihan/Higher level of education, more effective in following the training

Tingkat pengetahuan makin tinggi, semakin efektif mengikuti pelatihan/Higher level of education, more effective in following the training

Umur peserta pelatihan semakin tua, semakin tidak efektif mengikuti pelatihan/The maturity of training participants, more mature more effective in following the training

Masa kerja (lama bekerja) semakin lama, semakin efktif mengikuti pelatihan./Longer work tenure, more effective in following the training

Motivasi mengikuti pelatihan makin kuat, makin efektif pelatihan/ Stronger motivation of participant in following training, more effective in following the training

Keterampilan makin tinggi, makin efektif mengikuti pelatihan/More skillfull participant, more effective in following the training

Persepsi positif, makin efektif mengikuti pelatihan/ Participant's Positive Perception, more effective in following the training

Sikap positif saat mengikuti pelatihan, makin efektif pelatihan yang diikuti/Participant's Positive Attitude, more effective in following the training
Frekuensi Jawaban Responden/ Frequency of Respondent's Answer

$\begin{array}{llllll}1 & 2 & 3 & 4 & 5 & 6\end{array}$

$\begin{array}{llllll}0 & 3 & 2 & 15 & 28 & 57\end{array}$

$\begin{array}{llllll}1 & 2 & 7 & 17 & 30 & 38\end{array}$

$\begin{array}{llllll}0 & 3 & 2 & 9 & 43 & 48\end{array}$

$\begin{array}{llllll}6 & 16 & 7 & 14 & 36 & 26\end{array}$

$\begin{array}{llllll}0 & 2 & 1 & 8 & 32 & 62\end{array}$

$\begin{array}{llllll}1 & 47 & 3 & 12 & 38 & 47\end{array}$

$\begin{array}{llllll}1 & 2 & 4 & 6 & 33 & 59\end{array}$

$\begin{array}{llllll}3 & 3 & 5 & 11 & 58 & 45\end{array}$




\begin{tabular}{|c|c|c|c|c|c|}
\hline \multirow{2}{*}{$\begin{array}{c}\text { Indikator Kualitas Peserta Pelatihan Budidaya } \\
\text { Perikanan/Participant Quality Indicator of } \\
\text { Aquaculture Training }\end{array}$} & \multicolumn{5}{|c|}{$\begin{array}{l}\text { Frekuensi Jawaban Responden/ } \\
\text { Frequency of Respondent's Answer }\end{array}$} \\
\hline & 1 & 2 & 3 & 4 & 5 \\
\hline
\end{tabular}

Budaya (kebiasaan) berbudidaya perikanan semakin sama, semakin efektif mengikuti pelatihan/The Equality of Participant's Aqualture habitual, more effective in

$\begin{array}{llllll}2 & 0 & 3 & 14 & 47 & 39\end{array}$
following the training

Sumber daya (Sarana produksi) yang dimiliki peserta pelatihan semakin banyak kesamaan dengan sarana dalam pelatihan, semakin efektif pelatihan yang diikuti/ The equality sources (production means) which belonging to partipants more equal with training means, more effective in following the training
Indikator Kualitas Modul Pelatihan Budidaya Perikanan/Quality indicator of Aqualture Training Modules

Kelengkapan dari materi yang disajikan/Material Completeness which presented

$\begin{array}{llllll}0 & 3 & 6 & 12 & 48 & 36\end{array}$

Materi yang diberikan sesuai dengan kebutuhan peserta/

Presented material in accordance with participant's needs

Frekuensi Jawaban Responden/ Frequency of Respondent's Answer

Materi merupakan informasi atau keahlian yang baru/

Material is a new information or new skill

\begin{tabular}{llllll}
1 & 2 & 3 & 4 & 5 & 6 \\
\hline
\end{tabular}

Keteraturan dan sistematka dalam susunan materi/

Regularity and sistematika the structure of material

$\begin{array}{llllll}0 & 1 & 47 & 19 & 41 & 33 \\ 0 & 4 & 5 & 19 & 33 & 44 \\ 0 & 4 & 2 & 9 & 32 & 58 \\ 0 & 4 & 5 & 11 & 22 & 63\end{array}$

Indikator Ketepatan Metode Pelatihan
Budidaya Perikanan/ Accuracy Aqualture
Training Metode Indicator

Kesesuaian metode dengan latar belakang pendidikan dan Pengetahuan peserta/ Metode accuracy with Education and participant's skill background

\section{Frekuensi Jawaban Responden/} Frequency of Respondent's Answer

$\begin{array}{llllll}1 & 2 & 3 & 4 & 5 & 6\end{array}$

Kesesuaian metode dengan karier (tugas pekerjaan) peserta/ Metode accuracy with partipant's career (main job)

$\begin{array}{llllll}0 & 1 & 7 & 19 & 43 & 35\end{array}$

Kesesuaian metode dengan materi pelatihan yang disampaikan/ Metode accuracy with presented training $\quad \begin{array}{llllll}0 & 0 & 5 & 12 & 47 & 41\end{array}$ material

\begin{tabular}{llllllr}
\hline $\begin{array}{l}\text { Indikator Kualitas Pelatih Pelatihan Budidaya } \\
\text { Perikanan/Aqualture Trainer Quality Indicators }\end{array}$ & \multicolumn{4}{c}{$\begin{array}{c}\text { Frekuensi Jawaban Responden/ } \\
\text { Frequency of Respondent's Answer }\end{array}$} \\
\cline { 2 - 7 } & 1 & 2 & 3 & 4 & 5 & 6 \\
\hline $\begin{array}{l}\text { Pengalaman Pelatih/ Trainer Experience } \\
\text { Kemampuan Pelatih mentransfer materi/ }\end{array}$ & 0 & 0 & 1 & 7 & 31 & 66 \\
Trainer material Transfering Skill & 1 & 1 & 2 & 14 & 41 & 36 \\
\hline
\end{tabular}


Pengetahuan/Penguasaan Pelatih terhadap Materi yang dilatihkan/Trainer knowledge/mastery in trained material

\begin{tabular}{|c|c|c|c|c|c|c|}
\hline \multirow{2}{*}{$\begin{array}{c}\text { Indikator Efektivitas Pelatihan Budidaya Perikanan/ } \\
\text { Aqulture Training Effectivity Indicators }\end{array}$} & \multicolumn{6}{|c|}{$\begin{array}{l}\text { Frekuensi Jawaban Responden/ } \\
\text { Frequency of Respondent's Answer }\end{array}$} \\
\hline & 1 & 2 & 3 & 4 & 5 & 6 \\
\hline $\begin{array}{l}\text { Tambahan pengetahuan atau kemampuan peserta } \\
\text { pelatihan budidaya perikanan/Participant's knowledge or } \\
\text { skill increasing of aqualture training }\end{array}$ & 0 & 1 & 6 & 7 & 38 & 53 \\
\hline $\begin{array}{l}\text { Kemampuan peserta mengingat isi pelatihan budidaya } \\
\text { perikanan/Participants' ability to remember the contents } \\
\text { of aquaculture training }\end{array}$ & 1 & 6 & 9 & 31 & 43 & 15 \\
\hline $\begin{array}{l}\text { Kemampuan peserta mempraktikan materi pelatihan } \\
\text { budidaya perikanan/ The ability of the participants to } \\
\text { practice cultivation training materials }\end{array}$ & 1 & 3 & 9 & 17 & 44 & 31 \\
\hline \multirow{2}{*}{$\begin{array}{c}\text { Indikator Kinerja Pembudidaya Perikanan/ Farmers } \\
\text { Fisheries Performance Indicators }\end{array}$} & \multicolumn{6}{|c|}{$\begin{array}{l}\text { Frekuensi Jawaban Responden/ } \\
\text { Frequency of Respondent's Answer }\end{array}$} \\
\hline & 1 & 2 & 3 & 4 & 5 & 6 \\
\hline $\begin{array}{l}\text { Efisiensi penggunaan Luas kolam/tambak/ } \\
\text { Efficiency of pool/pond usage }\end{array}$ & 1 & 13 & 25 & 25 & 15 & 23 \\
\hline $\begin{array}{l}\text { Efisiensi penggunaan Pupuk/ } \\
\text { Efficiency of fertilizer usage }\end{array}$ & 10 & 1 & 13 & 20 & 41 & 20 \\
\hline $\begin{array}{l}\text { Efisiensi penggunaan Kapur/ } \\
\text { Efficiency of Kapur usage }\end{array}$ & 11 & 2 & 17 & 26 & 33 & 16 \\
\hline $\begin{array}{l}\text { Efisiensi penggunaan Benih/ } \\
\text { Efficiency of seed usage }\end{array}$ & 4 & 1 & 11 & 29 & 34 & 26 \\
\hline $\begin{array}{l}\text { Efisiensi penggunaan Pakan/ } \\
\text { Efficiency of weft usage }\end{array}$ & 11 & 22 & 11 & 12 & 29 & 30 \\
\hline $\begin{array}{l}\text { Efisiensi penggunaan Obat obatan dan probiotik/ } \\
\text { Efficiency of medicine and probiotic usage }\end{array}$ & 15 & 1 & 15 & 21 & 24 & 29 \\
\hline $\begin{array}{l}\text { Efisiensi penggunaan Tenaga kerja/ } \\
\text { Efficiency of man power usage }\end{array}$ & 17 & 16 & 10 & 14 & 29 & 19 \\
\hline $\begin{array}{l}\text { Pengalaman kerja pembudidaya perikanan/ } \\
\text { Farmer fisheries work experience }\end{array}$ & 10 & 9 & 12 & 17 & 21 & 36 \\
\hline
\end{tabular}

\section{Analisis Faktor Konfirmatori (Confirmatory Factor Analysis)}

Analisis faktor konfirmatori merupakan tahap pengukuran terhadap indikatorindikator yang membentuk variabel laten dalam model penelitian. Disebut sebagai teknik analisis faktor konfirmatori sebab pada tahap ini model akan mengkonfirmasi apakah indikator yang diamati dapat mencerminkan faktor yang dianalisis. Unidimensionalitas dari dimensi-dimensi itu diuji melalui confirmatory faktor analysis, hasilnya seperti yang disajikan.

\section{Analisis Konfirmatori Konstruk Eksogen}

Tahap analisis konstruk eksogen bertujuan menguji unidimensional dari dimensi-dimensi pembentuk masing-masing variabel laten eksogen. Variabel-variabel laten atau konstruk ini terdiri dari 5 unobserved variable yaitu sarana pelatihan (X1), kualitas peserta pelatihan (X2), kualitas isi modul (X3), ketepatan metode pelatihan (X4) dan kualitas pelatih (X5) dengan 24 observed variable sebagai indikator pembentuknya. Hasil pengolahan data yaitu sebagai berikut: 
Uji Signifikansi Bobot Faktor dan Uji Kelayakan Model

Uji ini untuk menguji apakah suatu indikator dapat digunakan untuk mengkonfirmasi bahwa indikator tersebut dapat bersama-sama dengan indikator lainnya dalam menjelaskan suatu variabel laten, yang dikaji dengan menggunakan dua tahapan analisis (Ferdinand, 2005:284) yaitu Regression Weight Analisis Faktor Konfirmatori dan Pengujian Kelayakan Model. Berdasarkan hasil uji Regression Weight semua indikator pada tiap variabel masingmasing indikator memiliki nilai $\mathrm{CR}>1,96$ dan tingkat signifikansi $<0.05$, hal ini menunjukkan bahwa indikator-indikator tersebut secara signifikan merupakan dimensi dari faktor laten yang dibentuk.

Tabel 3. Regression Weight Analisis Faktor Konfirmatori Konstruk Eksogen.

Table 3. Confirmatory Factor Analysis Regression Weight Exogenous Constructs.

\begin{tabular}{|c|c|c|c|c|c|c|c|}
\hline & & & Std Estimate & Estimate & S.E & C.R. & $\mathbf{P}$ \\
\hline X1.4 & $<---$ & $\begin{array}{l}\text { Sarana_Pelatihan }(\mathrm{X} 1) / \\
\text { Training means }\end{array}$ & .673 & 1.000 & & & \\
\hline $\mathrm{X} 1.3$ & $<---$ & $\begin{array}{l}\text { Sarana_Pelatihan (X1)/ } \\
\text { Training means }\end{array}$ & .709 & 1.333 & .220 & 6.067 & $* * *$ \\
\hline $\mathrm{X} 1.2$ & $<---$ & $\begin{array}{l}\text { Sarana_Pelatihan }(\mathrm{X} 1) \text { / } \\
\text { Training means }\end{array}$ & .684 & 1.271 & .215 & 5.906 & $* * *$ \\
\hline $\mathrm{X} 1.1$ & $<---$ & $\begin{array}{l}\text { Sarana_Pelatihan (X1) / } \\
\text { Training means }\end{array}$ & .679 & 1.992 & .332 & 5.992 & $* * *$ \\
\hline $\mathrm{X} 2.8$ & $<---$ & $\begin{array}{l}\text { Kualitas_Peserta (X2)/ } \\
\text { Quality of Participants }\end{array}$ & .530 & 1.110 & .250 & 4.438 & $* * *$ \\
\hline $\mathrm{X} 2.3$ & $<---$ & $\begin{array}{l}\text { Kualitas_Peserta (X2) / } \\
\text { Quality of Participants }\end{array}$ & .751 & 1.152 & .202 & 5.693 & $* * *$ \\
\hline$X 2.2$ & $<---$ & $\begin{array}{l}\text { Kualitas_Peserta (X2) / } \\
\text { Quality of Participants }\end{array}$ & .650 & 1.208 & .232 & 5.211 & $* * *$ \\
\hline$X 2.1$ & $<--$ & $\begin{array}{l}\text { Kualitas_Peserta (X2) / } \\
\text { Quality of Participants }\end{array}$ & .615 & 1.000 & & & \\
\hline X3.4 & $<---$ & $\begin{array}{l}\text { Kualitas_Modul (X3) / } \\
\text { Quality of Module }\end{array}$ & .697 & 1.000 & & & \\
\hline X3.3 & $<---$ & $\begin{array}{l}\text { Kualitas_Modul (X3) / } \\
\text { Quality of Module }\end{array}$ & .747 & .965 & .169 & 5.705 & $* * *$ \\
\hline $\mathrm{X} 3.2$ & $<---$ & $\begin{array}{l}\text { Kualitas_Modul (X3) / } \\
\text { Quality of Module }\end{array}$ & .794 & 1.115 & .153 & 7.275 & $* * *$ \\
\hline X3.1 & $<---$ & $\begin{array}{l}\text { Kualitas_Modul (X3) / } \\
\text { Quality of Module }\end{array}$ & .721 & 1.088 & .163 & 6.697 & $* * *$ \\
\hline X4.3 & $<---$ & $\begin{array}{l}\text { Ketepatan_Metode } \\
\text { (X4) / Accuracy of } \\
\text { Methode }\end{array}$ & .668 & 1.000 & & & \\
\hline$X 4.2$ & $<---$ & $\begin{array}{l}\text { Ketepatan_Metode } \\
\text { (X4) / Accuracy of } \\
\text { Methode }\end{array}$ & .664 & 1.393 & .241 & 5.775 & $* * *$ \\
\hline X4.1 & $<--$ & $\begin{array}{l}\text { Ketepatan_Metode } \\
\text { (X4) / Accuracy of } \\
\text { Methode }\end{array}$ & .789 & 1.348 & .207 & 6.511 & $* * *$ \\
\hline X5.3 & $<---$ & $\begin{array}{l}\text { Kualitas_Pelatih (X5) / } \\
\text { Quality of Trainer }\end{array}$ & .504 & 1.000 & & & \\
\hline X5.2 & $<---$ & $\begin{array}{l}\text { Kualitas_Pelatih (X5) / } \\
\text { Quality of Trainer }\end{array}$ & .525 & 1.065 & .198 & 5.391 & $* * *$ \\
\hline X5.1 & $<--$ & $\begin{array}{l}\text { Kualitas_Pelatih (X5) / } \\
\text { Quality of Trainer }\end{array}$ & .870 & 1.292 & .301 & 4.297 & $* * *$ \\
\hline
\end{tabular}

$* * *$ = tingkat signifikansi $<0.01$ 
Tetapi masih ada indikator X2.4, $\mathrm{X} 2.5$, dan X2.9, dengan nilai standardized loading factor $<0,5$, sehingga tidak dapat diikutsertakan dalam analisis dan harus dilakukan modifikasi. Setelah dilakukan modifikasi diperoleh hasil sebagai berikut:

\section{a. Nilai Critical Rasio (CR)}

Bobot faktor menunjukkan kuatnya dimensi-dimensi itu membentuk faktor latennya. Bobot faktor dapat dianalisis dengan menggunakan uji-t yang dalam analisis SEM uji-t identik dengan nilai Critical Ratio (CR). Berdasarkan hasil yang disajikan dalam Tabel 20 tampak bahwa masing-masing indikator memiliki nilai $\mathrm{CR}>1,96$ dan tingkat signifikansi $<0.05$, hal ini menunjukkan bahwa indikator-indikator tersebut secara signifikan merupakan dimensi dari faktor laten yang dibentuk.

Tabel 4. Hasil Pengujian Kelayakan Model pada Konstruk Eksogen.

Table 4. Results of Feasibility Testing Model to Exogenous Constructs.

\begin{tabular}{cccc}
\hline Goodness of Fit Index & Cut off Value & $\begin{array}{c}\text { Hasil/ } \\
\text { Result }\end{array}$ & $\begin{array}{c}\text { Evaluasi Model/ } \\
\text { Model Evaluation }\end{array}$ \\
\hline Chi-Square & $\begin{array}{c}\leq 132,144\left(\chi_{\text {tabel }}^{2} \text { dengan }\right. \\
\text { db:127 dan p:5\%) }\end{array}$ & 123,806 & Baik/ Good \\
Probability & $\geq 0.05$ & 0.127 & Baik/ Good \\
RMSEA & $\leq 0.08$ & 0.039 & Baik/ Good \\
GFI & $\geq 0.90$ & 0.891 & Marginal \\
AGFI & $\geq 0.90$ & 0.852 & Marginal \\
CMIN/DF & $\leq 2.00$ & 1.157 & Baik/ Good \\
TLI & $\geq 0.95$ & 0.970 & Baik/Good \\
CFI & $\geq 0.95$ & 0.979 & Baik/Good \\
\hline
\end{tabular}

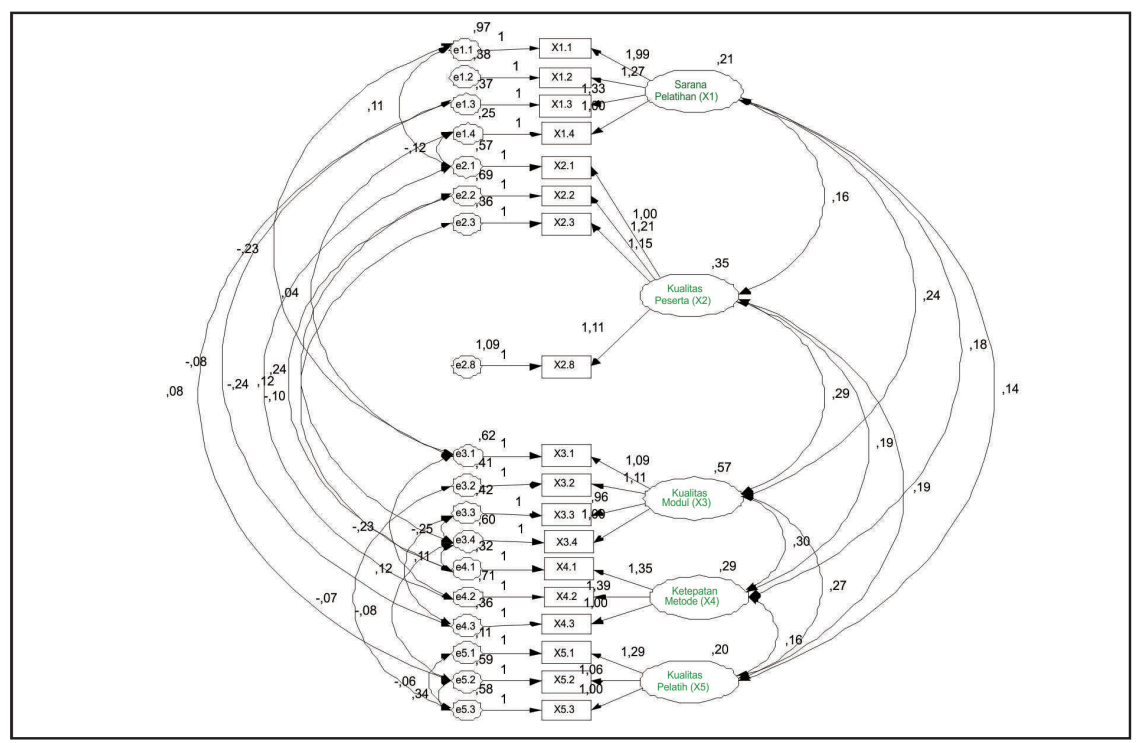

Gambar 1. Analisis Faktor Konfirmatori Konstruk Eksogen Setelah Modifikasi Figure 1. Confirmatory Factor Analysis of Constructs Exogenous After Modification 


\section{b. Nilai lambda atau faktor loading (bobot faktor)}

Berdasarkan hasil dari Tabel 3 dapat dilihat besarnya factor loading untuk tiap-tiap indikator. Suatu indikator dapat digunakan sebagai pengukur variabel laten jika memiliki nilai standardized factor loading $\geq 0,5$. Dari hasil analisis yang telah dilakukan, tidak terdapat indikator dengan nilai standardized loading factor $<0,5$ sehingga semua indikator dapat diikutsertakan dalam analisis selanjutnya. Selanjutnya, evaluasi terhadap uji kelayakan model ini disajikan pada Tabel 4 berikut ini:

Hasil Tabel 4 chi square yang kecil $(123,806<132,144)$ dan nilai probabilitas di atas 0,05 yaitu sebesar 0,127 . Hal ini berarti bahwa hipotesis nol yang menyatakan bahwa tidak terdapat perbedaan matrix covarian sampel dengan matriks covarian populasi yang diestimasi dapat diterima. Selain itu, nilai TLI $(0,970>0,9)$, CFI $(0,979>0,9)$, CMIN/ DF $(1,157<2,00)$ dan RMSEA $(0,039<0,08)$ juga memenuhi persyaratan. Sedangkan untuk nilai GFI dan AGFI masih termasuk dalam kriteria marginal (masih bisa dipertimbangkan).

Dengan demikian, dapat disimpulkan bahwa model yang dikembangkan telah memenuhi persayaratan kelayakan model.

\section{Analisis Konfirmatori Konstruk Endogen}

Tahap analisis konstruk endogen bertujuan menguji unidimensional dari dimensidimensi pembentuk masing-masing variabel laten endogen. Variabel-variabel laten atau konstruk ini terdiri dari 2 unobserved variable yaitu efektivitas pelatihan budidaya perikanan dan efisiensi kinerja pembudidaya perikanan dengan 11 observed variable sebagai indikator pembentuknya. Hasil pengolahan data yaitu sebagai berikut:

Tabel 5. Regression Weight Analisis Faktor Konfirmatori Konstruk Endogen Setelah Modifikasi.

Table 5. Confirmatory Factor Analysis Regression Weight After Modification of Endogenous Constructs.

\begin{tabular}{|c|c|c|c|c|c|c|c|}
\hline & & & Std Estimate & Esti mate & S.E. & C.R. & $\mathbf{P}$ \\
\hline $\begin{array}{c}\text { Efisiensi } \\
\text { Kinerja (Y2)/ } \\
\text { Performance } \\
\text { Efficiency (Y2) }\end{array}$ & $<--$ & $\begin{array}{c}\text { Efektivitas_Pelatihan (Y1)/ } \\
\text { Training Effectivity (Y1) }\end{array}$ & .534 & 1.145 & .371. & 3.088 & .002 \\
\hline Y1.1 & $<---$ & $\begin{array}{l}\text { Efektivitas_Pelatihan (Y1)/ } \\
\text { Training Effectivity (Y1) }\end{array}$ & .508 & 1.000 & & & \\
\hline Y1.2 & $<---$ & $\begin{array}{l}\text { Efektivitas_Pelatihan (Y1)/ } \\
\text { Training Effectivity (Y1) }\end{array}$ & .811 & 1.928 & .480 & 4.016 & $* * *$ \\
\hline Y1.3 & $<---$ & $\begin{array}{l}\text { Efektivitas_Pelatihan (Y1)/ } \\
\text { Training Effectivity (Y1) }\end{array}$ & .575 & 1.369 & .349 & 3.922 & $* * *$ \\
\hline Y2.2 & $<---$ & $\begin{array}{l}\text { Efisiensi_Kinerja (Y2)/ } \\
\text { Performance Efficiency (Y2) }\end{array}$ & .680 & 1.000 & & & \\
\hline Y2.3 & $<---$ & $\begin{array}{l}\text { Efisiensi_Kinerja (Y2)/ } \\
\text { Performance Efficiency (Y2) }\end{array}$ & .632 & .938 & .206 & 4.555 & $* * *$ \\
\hline Y2.5 & $<---$ & $\begin{array}{l}\text { Efisiensi_Kinerja (Y2)/ } \\
\text { Performance Efficiency (Y2) }\end{array}$ & .751 & 1.314 & .427 & 3.079 & .002 \\
\hline Y2.6 & $<--$ & $\begin{array}{l}\text { Efisiensi_Kinerja (Y2)/ } \\
\text { Performance Efficiency (Y2) }\end{array}$ & .793 & 1.355 & .322 & 4.211 & $* * *$ \\
\hline Y2.7 & $<---$ & $\begin{array}{l}\text { Efisiensi_Kinerja (Y2)/ } \\
\text { Performance Efficiency (Y2) }\end{array}$ & ,650 & 1,157 & 245, & 4,718 & $* * *$ \\
\hline
\end{tabular}




\section{Uji Signifikansi Bobot Faktor dan Uji Kelayakan Model}

Uji ini dilakukan untuk menguji apakah suatu indikator dapat digunakan untuk mengkonfirmasi bahwa indikator tersebut dapat bersama-sama dengan indikator lainnya dalam menjelaskan suatu variabel laten, yang dikaji dengan menggunakan dua tahapan analisis (Ferdinand, 2005:284) yaitu Regression Weight Analisis Faktor Konfirmatori dan Pengujian Kelayakan Model.

Berdasarkan hasil uji Regression Weight semua indikator pada tiap variabel masing-masing indikator memiliki nilai CR > 1,96 dan tingkat signifikansi $<0.05$, hal ini menunjukkan bahwa indikator-indikator tersebut secara signifikan merupakan dimensi dari faktor laten yang dibentuk. Tetapi ada indikator yang memiliki nilai loading factor $<0,5$ yaitu indikator Y2.4 $(0,483)$ dan Y2.1 $(0,455)$, sehingga indikator tersebut tidak dapat diikutsertakan dalam analisis selanjutnya dan harus dilakukan modifikasi. Setelah dilakukan modifikasi diperoleh hasil sebagai berikut :

\section{a. Nilai Critical Rasio (CR)}

Bobot faktor menunjukkan kuatnya dimensi-dimensi itu membentuk faktor latennya. Bobot faktor dapat dianalisis dengan menggunakan uji-t yang dalam analisis SEM uji-t identik dengan nilai Critical Ratio (CR). Berdasarkan hasil yang disajikan dalam Tabel 4 tampak semua indikator memiliki nilai CR
$>2.0$ dan tingkat signifikansi $<0.05$, hal ini menunjukkan bahwa indikator-indikator tersebut secara signifikan merupakan dimensi dari faktor laten yang dibentuk.

\section{b. Nilai lambda atau faktor loading (bobot faktor)}

Dari Tabel 5 dapat dilihat besarnya factor loading untuk tiap-tiap indikator. Suatu indikator dapat digunakan sebagai pengukur variabel laten jika memiliki nilai factor loading $\geq 0,5$. Dari hasil analisis yang dilakukan, diketahui semua indikator memiliki nilai loading factor $>0,5$ sehingga semua indikator dapat diikutsertakan dalam analisis selanjutnya. Analisis pada Tabel 5 juga menunjukkan hasil uji kelayakan model. Suatu model dikatakan layak jika hasil cut of value memenuhi persyaratan. Evaluasi terhadap uji kelayakan model ini selanjutnya disajikan pada Tabel 6.

Tabel 6 menunjukkan nilai chi square yang kecil $(14,085<18,307)$ dan nilai probabilitas di atas 0,05 yaitu sebesar 0,169. Hal ini berarti bahwa hipotesis nol yang menyatakan bahwa tidak terdapat perbedaan antara matrix covarian sampel dengan matriks covarian populasi yang diestimasi dapat diterima. Selain itu, nilai GFI $(0,969>0,9)$, AGFI $(0,80<0,890<0,9)$, TLI $(0,954>0,9)$, CFI $(0,983>0,9)$, CMIN/DF $(1,408<2,00)$ dan RMSEA $(0,063<0,08)$ juga memenuhi persyaratan.

Tabel 6. Hasil Pengujian Kelayakan Model pada Variabel Endogen.

Table 6. Feasibility Model Testing Results on Endogenous Variables.

\begin{tabular}{cccc}
\hline Goodness of Fit Index & Cut off Value & Hasil/ Result & $\begin{array}{c}\text { Evaluasi Model/ } \\
\text { Model Evaluation }\end{array}$ \\
\hline Chi-Square & $\begin{array}{c}18,307\left(\chi_{\text {tabel }}^{2} \text { dengan }\right. \\
\mathrm{db}: 43 \text { dan } \mathrm{p}: 5 \%)\end{array}$ & 14,085 & Baik/Good \\
Probability & $\geq 0.05$ & 0.169 & Baik/Good \\
RMSEA & $\leq 0.08$ & 0.063 & Baik/Good \\
GFI & $\geq 0.90$ & 0.969 & Baik/Good \\
AGFI & $\geq 0.90$ & 0.890 & Marginal \\
CMIN/DF & $\leq 2.00$ & 1.408 & Baik/Good \\
TLI & $\geq 0.95$ & 0.954 & Baik/Good \\
CFI & $\geq 0.95$ & 0.983 & Baik/Good \\
\hline
\end{tabular}




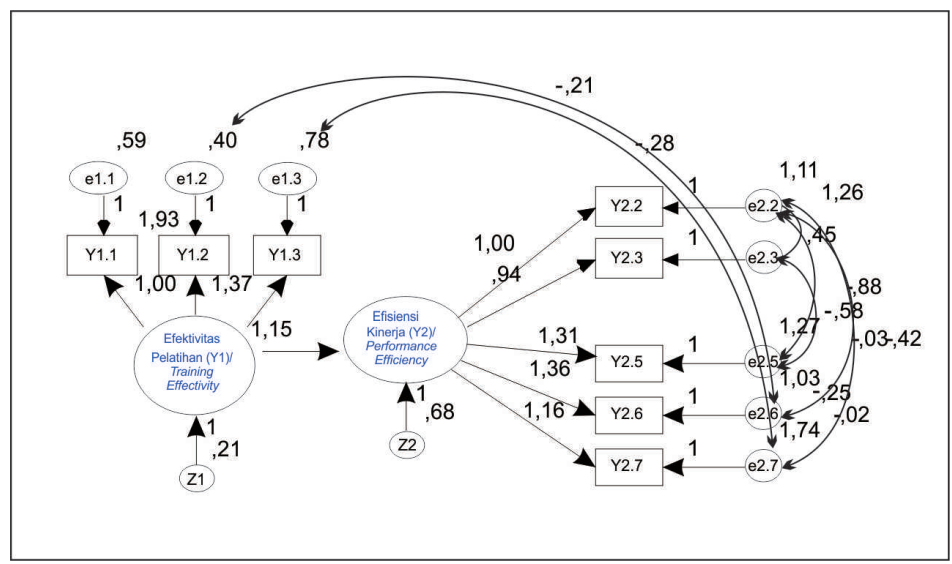

Gambar 2. Analisis Faktor Konfirmatori Konstruk Endogen Setelah Modifikasi.

Figure 2. Confirmatory Factor Analysis of Endogenous Constructs After Modification.

Dengan demikian, dapat disimpulkan bahwa model yang dikembangkan telah memenuhi persayaratan kelayakan model.

\section{Analisis Full Model Structural Equation Modeling (SEM)}

Setelah melakukan analisis measurement model melalui konfirmatori faktor analisis dan dilihat bahwa masing-masing indikator dapat digunakan untuk mendefinisikan sebuah konstruk laten, maka sebuah full model SEM dapat dianalisis.

Analisis hasil pengolahan data pada tahap full model SEM dilakukan dengan melakukan uji kesesuaian dan uji statistic. Hasil pengolahan data untuk analisis full model SEM ditampilkan pada Gambar 3

Model SEM selanjutnya diuji dengan dua macam pengujian, yaitu kesesuaian model serta uji signifikansi kausalitas melalui uji koefisien regresi (Ferdinand, 2005).

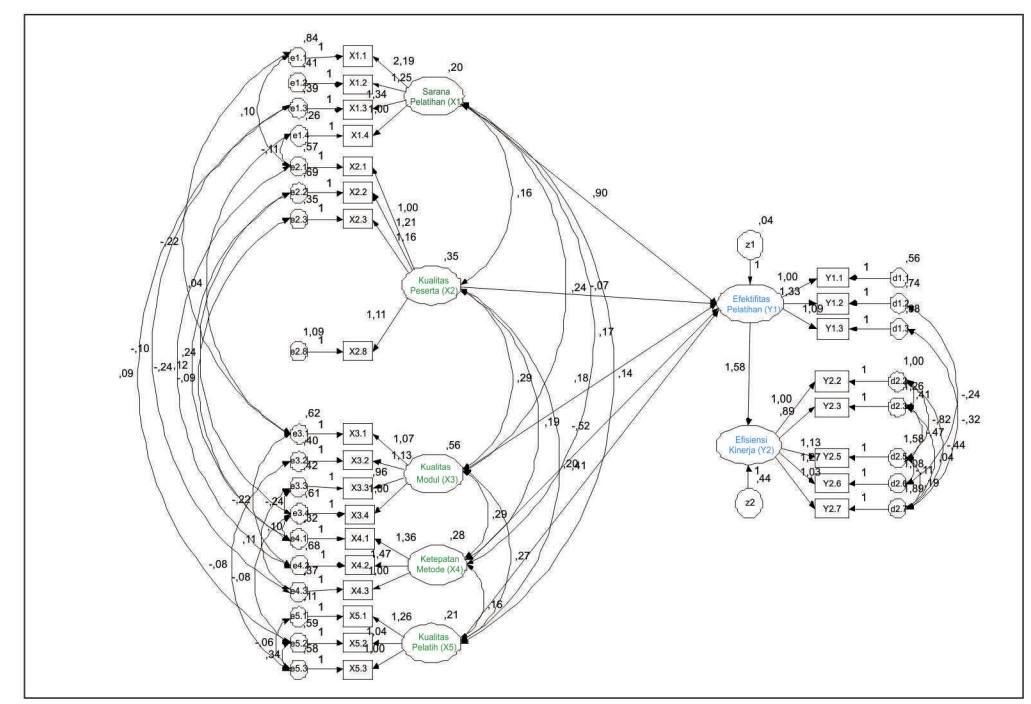

Gambar 3. Analisis Full Model.

Figure 3. Analysis of Full Model. 


\section{Uji Kesesuaian Model - Goodness of Fit Test}

Indeks-indeks kesesuaian model yang digunakan sama seperti pada konfirmatori faktor analisis. Pengujian model SEM bertujuan untuk melihat kesesuaian model. Hasil pengolahan yang dilakukan disajikan dalam Tabel 7 .

Dari Tabel 7 menunjukkan chi square yang besar $(415,164>294,321)$ dan nilai probabilitas di bawah 0,05 yaitu sebesar 0,000 . Hal ini berarti bahwa hipotesis nol yang menyatakan bahwa tidak terdapat perbedaan antara matrix covarian sampel dengan matriks covarian populasi yang diestimasi tidak dapat terima. Namun terdapat beberapa nilai goodness of fit yang memenuhi persyaratan seperti CMIN/DF $(1,622<2,00)$ dan RMSEA $(0,077<0,08)$. Sedangkan nilai GFI $(0,787$ $<0,90)$, nilai TLI $(0,871<0,95)$ dan, AGFI $(0,70<0,90)$ yang masih memenuhi batas margin sehingga model yang dikembangkan masih dapat dipertimbangkan. Berdasarkan prinsip parsimony yang menyatakan bahwa paling tidak terdapat dua criteria goodness of fit yang termasuk good fit, maka dapat dikatakan bahwa model sudah bisa digunakan dalam penelitian ini.

\section{Pengujian Hipotesis Efektivitas Pelatihan}

Hasil pengujian terhadap hipotesis yang diajukan dalam penelitian ini secara ringkas ditunjukkan pada Tabel 8.

\section{Faktor sarana/media pelatihan budidaya perikanan}

Variabel sarana/media pelatihan budidaya perikanan berpengaruh positif signifikan terhadap variabel efektivitas pelatihan budidaya perikanan yang dilakukan. Hasil penelitian ini sesuai dengan Makokha dan Ongwae (2007) yang menyatakan bahwa sarana / benda bantu digunakan untuk membantu instruktur dalam persiapan pelajaran, presentasi (mengajar) pelajaran dan memfasilitasi belajar trainee. Pendapat tersebut juga diperkuat oleh Marpaung dan Giri (2003) yang menyatakan bahwa dengan pemilihan media komunikasi yang tepat dapat memaksimalkan pencapaian tujuan komunikasi .

\section{Faktor kualitas peserta pelatihan budidaya perikanan}

Kualitas peserta pelatihan tidak berpengaruh signifikan dan negatif terhadap variabel efektivitas pelatihan budidaya

Tabel 7. Hasil Pengujian Kelayakan Model pada Full Model.

Table 7. Feasibility Test Results on the Full Model Model.

\begin{tabular}{cccc}
\hline Goodness of Fit Index & Cut off Value & $\begin{array}{c}\text { Hasil/ } \\
\text { Result }\end{array}$ & $\begin{array}{c}\text { Evaluasi Model/ } \\
\text { Model Evaluation }\end{array}$ \\
\hline Chi-Square & $\begin{array}{c}\leq 294,321\left(\chi_{\text {tabel }}^{2} \text { dengan }\right. \\
\text { db:256 dan p:5\%) }\end{array}$ & 415,164 & Tidak Baik/Bad \\
Probability & $\geq 0,05$ & 0,000 & Tidak Baik/Bad \\
RMSEA & $\leq 0,08$ & 0,077 & Baik/Good \\
GFI & $\geq 0,90$ & 0,787 & Marginal \\
AGFI & $\geq 0,90$ & 0,707 & Tidak Baik/Bad \\
CMIN/DF & $\leq 2,00$ & 1,622 & Baik/Good \\
TLI & $\geq 0,95$ & 0,836 & Marginal \\
CFI & $\geq 0,95$ & 0,871 & Marginal \\
\hline
\end{tabular}


Tabel 8. Pengujian Hipotesis/Kausalitas.

Table 8. Hypothesis Testing / Causality.

\begin{tabular}{|c|c|c|c|c|c|c|c|c|}
\hline & & & $\begin{array}{l}\text { Std Esti } \\
\text { mate }\end{array}$ & $\begin{array}{l}\text { Esti } \\
\text { mate }\end{array}$ & S.E. & C.R. & $P$ & $\begin{array}{c}\text { Keputusan/ } \\
\text { Decision }\end{array}$ \\
\hline $\begin{array}{l}\text { Efektifitas_Pelatihan (Y1)/ } \\
\text { Training Effectivity (Y1) }\end{array}$ & $<---$ & $\begin{array}{l}\text { Sarana Pelatihan } \\
\text { (X1)/Training } \\
\text { Means (X1) }\end{array}$ & .819 & .903 & .297 & 3.044 & .002 & $\begin{array}{l}\text { Signifikan/ } \\
\text { Significant }\end{array}$ \\
\hline $\begin{array}{l}\text { Efektifitas_Pelatihan (Y1)/ } \\
\text { Training Effectivity (Y1) }\end{array}$ & $<---$ & $\begin{array}{l}\text { Kualitas Peserta } \\
\text { (X2)/ Quality of } \\
\text { Participants (X2) }\end{array}$ & -.085 & -.071 & .172 & -.415 & .678 & $\begin{array}{l}\text { Tidak } \\
\text { Signifikan/ } \\
\text { Not Signifi- } \\
\text { cant }\end{array}$ \\
\hline $\begin{array}{l}\text { Efektifitas_Pelatihan (Y1)/ } \\
\text { Training Effectivity (Y1) }\end{array}$ & $<---$ & $\begin{array}{l}\text { Kualitas Modul } \\
\text { (X3)/ Quality of } \\
\text { Module (X3) }\end{array}$ & .277 & .182 & .165 & 1.102 & .271 & $\begin{array}{l}\text { Tidak } \\
\text { Signifikan/ } \\
\text { Not Signifi- } \\
\text { cant }\end{array}$ \\
\hline $\begin{array}{l}\text { Efektifitas_Pelatihan }(\mathrm{Y} 1) \text { / } \\
\text { Training Effectivity }(\mathrm{Y} 1)\end{array}$ & $<---$ & $\begin{array}{l}\text { Ketepatan } \\
\text { Metode (X4)/ } \\
\text { Accuracy of } \\
\text { Methode (X4) }\end{array}$ & -.556 & -.516 & .227 & -2.269 & .023 & $\begin{array}{l}\text { Signifikan/ } \\
\text { Significant }\end{array}$ \\
\hline $\begin{array}{l}\text { Efektifitas_Pelatihan (Y1)/ } \\
\text { Training Effectivity (Y1) }\end{array}$ & $<---$ & $\begin{array}{l}\text { Kualitas Pelatih } \\
\text { (X5)/ Quality of } \\
\text { Trainer (X5) }\end{array}$ & .375 & .406 & .342 & 1.187 & .235 & $\begin{array}{l}\text { Tidak } \\
\text { Signifikan/ } \\
\text { Not Signifi- } \\
\text { cant }\end{array}$ \\
\hline $\begin{array}{l}\text { Efisiensi_Kinerja (Y2)/ } \\
\text { Performance Efficiency (Y2) }\end{array}$ & $<---$ & $\begin{array}{l}\text { Efektifitas } \\
\text { Pelatihan (Y1)/ } \\
\text { Training } \\
\text { Effectivity (Y1) }\end{array}$ & .760 & 1.585 & .371 & 4.272 & $* * *$ & $\begin{array}{l}\text { Signifikan/ } \\
\text { Significant }\end{array}$ \\
\hline
\end{tabular}

perikanan yang dilakukan. Temuan ini merupakan hal yang serius dan mendesak untuk segera mendapat perhatian dan tindak lanjut agar variabel ini tidak menjadikan permasalahan terhadap efektivitas pelatihan yang dilakukan. Hal ini bertentangan dengan pendapat Shahril Bin Baharim (2008) yang menyatakan bahwa banyak peneliti telah mengakui bahwa transfer pelatihan akan terjadi hanya ketika trainee memiliki motivasi atau keinginan untuk menggunakan pengetahuan dan keterampilan yang dipelajari pada pekerjaan. Temuan ini diduga karena adanya perbedaan pada indikator tingkat pendidikan antar peserta yang terlalu tinggi dan perbedaan umur antar peserta yang terlalu jauh berbeda, serta adanya dominasi peserta dengan usia mendekati usia tidak produktif (mendekati 55 tahun sebesar 25,7 \%). Hal ini sesuai dengan pendapat (World Health Organization, 2001) menemukan bahwa pekerja yang lebih tua melaporkan keluhan kesehatan lebih sering dari pekerja muda.

\section{Kualitas isi bahan ajar pelatihan budidaya perikanan}

Variabel ini tidak berpengaruh signifikan terhadap Efektifitas Pelatihan. Temuan ini merupakan hal yang serius dan mendesak untuk segera mendapat perhatian dan tindak lanjut untuk mendapatkan solusi. Kualitas bahan ajar berdasarkan indikator kelengkapan dari materi yang diberikan, kesesuaian isi materi dengan kebutuhan pelatihan, sistematika dari isi modul dan indikator bahwa modul yang disampaikan merupakan informasi yang baru bagi peserta pelatihan ini tidak mempunyai pengaruh yang signifikan diduga karena berdasarkan hasil pengamatan langsung terhadap modul-modul yang gunakan kurang memberikan informasi yang lengkap terhadap kebutuhan yang diperlukan oleh peserta pelatihan, walaupun isi materinya merupakan informasi yang baru dan sistematis, tetapi karena jumlah informasinya terlalu sedikit (tidak lengkap), maka berdampak pada tidak terpenuhinya kebutuhan materi yang 
diperlukan. Hal ini sesuai dengan pendapat (Kenny, 1996) bahwa persyaratan bahan ajar yaitu volume bahan, diperlukan keseimbangan untuk memastikan peserta tidak merasa kewalahan dengan materi, tetapi mereka juga tahu bahan referensi untuk studi lebih lanjut jika mereka memilih untuk mempelajari topik lebih terinci. Modul harus meliputi ranah kognitif, psikomotor dan afektif serta modul yang dibuat harus aktual/terkini.

\section{Faktor ketepatan metode pelatihan budidaya perikanan.}

Variabel kualitas Ketepatan Metode pelatihan berdasarkan hasil pengujian, berpengaruh tetapi tidak signifikan dan arahnya negatif terhadap Efektifitas Pelatihan budidaya perikanan yang dilakukan. Hasil penelitian ini tidak sesuai dengan pendapat Halim dan Ali (1997) untuk mencapai tujuan pelatihan, pelatih harus memilih metode pelatihan yang paling sesuai dengan isi, untuk melibatkan peserta dalam proses pembelajaran dan lebih lanjut dijelaskan bahwa pelatihan memiliki peluang kesuksesan yang lebih baik ketika metode pelatihan dipilih secara cermat.

Berkaitan dengan hal tersebut, ketepatan metode pelatihan akan menjadi masalah yang serius terhadap efektifitas pelatihan. Berdasarkan hasil analisis konfirmatori, keadaan ini diduga karena adanya pengaruh dari variabel lain seperti variabel kualitas peserta, khususnya dari indikator tingkat pendidikan , (hasil analisis konfirmatori kedua variabel tersebut saling mempengaruhi dengan arah koefisien negatif $(-0,24)$ dan $(-0,09)$ indikator umur peserta, sehingga semakin memberi pengaruh kearah negatif terhadap variabel efektivitas pelatihan

\section{Kualitas Pelatih}

Variabel kualitas pelatih tidak berpengaruh signifikan terhadap efektivitas pelatihan, variabel kualitas pelatih yang diukur berdasarkan indikator pengalaman pelatih, kemampuan pelatih mentransfer materi dan penguasaan pelatih terhadap materi yang dilatihkan ternyata tidak berpengaruh signifikan, variabel ini tentunya akan berpotensi menjadi masalah yang serius terhadap efektivitas pelatihan yang diselenggarakan .

Hasil temuan dalam penelitian ini bertentangan dengan pendapat dari Marpaung dan Giri (2003) menjelaskan strategi pembelajaran yang komunikatif bagi pelatih yang profesiaonal secara umum yaitu dapat dinilai dari kemampuannya mengembangkan kompetensi diri dan keterampilan melakukan tugas dan tanggungjawab yang berhubungan dengan pengajaran.

Berdasarkan hasil analisis konfirmatori , variabel kualitas pelatih terutama dipengaruhi oleh indikator pengalaman pelatih dengan koefisien 1,26 kemudian disusul indikator penguasaan pelatih mentransfer materi 1,04 . Berdasarkan pengamatan langsung oleh peneliti, diperoleh fakta bahwa adanya pelatih budidaya perikanan yang memilki pengalaman melatih relatif belum lama (kurang dari 5 tahun ) berjumlah $43 \%$ dari pelatih budidaya perikanan yang ada di BPPP Banyuwangi (Laporan Tahunan BPPP Banyuwangi, 2010 diolah). Indikator penguasan pelatih dalam mentransfer materi pelatihan diduga berkorelasi kuat dengan indikator pengalaman pelatih.

\section{Efektivitas Pelatihan Budidaya Perikanan vs Efisiensi Kinerja Pembudidaya Perikanan.}

Hasil penelitian menunjukkan bahwa variabel efektivitas pelatihan budidaya perikanan berpengaruh signifikan terhadap Efisiensi Kinerja Pembudidaya Perikanan dan memberikan pengaruh secara langsung terhadap efisiensi kinerja pembudidaya perikanan sebesar $76,0 \%$. Hasil penelitian ini sama dengan hasil penelitian (Aqmala, 2007) yang menyatakan bahwa semakin tinggi efektivitas pelatihan penjualan maka semakin tinggi kinerja tenaga penjualan.

Hal ini artinya bahwa walaupun secara sendiri-sendiri ada tiga variabel yang tidak mempengaruhi secara signifikan, tetapi secara bersama sama variabel -variabel 
tersebut ternyata memberikan pengaruh yang signifikan terhadap variabel kinerja yang dilakukan purnawidya pelatihan budidaya perikanan.

\section{KESIMPULAN DAN IMPLIKASI KEBIJAKAN}

Berdasarkan hasil analisis seperti tersebut di atas maka untuk meningkatkan efektivitas pelaksanaan pelatihan budidaya perikanan di BPPP Banyuwangi maka BPPP Banyuwangi disarankan untuk mempertahankan penggunaan sarana atau media alat bantu pelatihan yang sudah ada dan dipergunakan dalam pelatihan budidaya perikanan. Peserta pelatihan budidaya perikanan agar diberikan materi dasar (pengantar tentang dasar-dasar budidaya perikanan), mengingat peserta yang mengikuti pelatihan budidaya perikanan memiliki latar belakang disiplin ilmu pendidikan formal yang berbeda-beda (Semacam Program Matrikulasi pada Pendidikan di Perguruan Tinggi).

Kemudian, bahan ajar/modul pelatihan perlu ditingkatkan dari segi kelengkapan isi materi, sehingga informasi secara lengkap tetang materi budidaya perikanan yang diperlukan oleh peserta dapat diperoleh dari modul pelatihan. Mempertahankan penggunaan metode yang selama ini telah digunakan. Dan tetap memperbaharui jika ada perkembangan metode baru. Pelatih budidaya perikanan perlu lebih banyak lagi mengkaji tentang pengembangan teknologi khususnya pada komoditas perikanan yang akan dilatihkan, lebih banyak memahami latar belakang sosial, budaya dan pendidikan peserta pelatihan.

\section{DAFTAR PUSTAKA}

Anonim. 2010. Peraturan Menteri Kelautan dan Perikanan Republik Indonesia Nomor Per. 06/MEN/2010, Tentang Rencana Strategis Kementerian Kelautan dan Perikanan Tahun 2010 - 2014 Menteri Kelautan dan Perikanan Republik Indonesia.
Aqmala, D. 2007. Analisis Faktor -faktor yang mempengaruhi Efektivitas Pelatihan Penjualan dan Kompetensi Relasional untuk meningkatkan Kinerja Tenaga Penjualan, (Tesis).

Halim, A., and Md. Mozahar Ali . 1998. Improving Agricultural Extension. A reference manual, Food and Agriculture Organization of the United Nations Rome.

Ferdinand, A. 2002. Structural Equation Modelling dalam Penelitian Manajemen, edisi 2, Fakultas Ekonomi Universitas Diponegoro. Semarang.

Ferdinand, A. 2005. Structural Equation Modeling dalam Penelitian Manajemen, edisi 3, BP. Fakultas Ekonomi Universitas Diponegoro. Semarang.

Gujarati, D. N . 1995. Third Edition Basics Econometrics, McGraw-Hill. New York.

Ghani, A., A. M Samupwa, dan N.J. Alzaidiyeen. 2009. The Effects of Teacher Training Programme on Teachers Productivity in Caprivi Region, Namibia

Ghozali, I. 2007. Aplikasi Analisis Multivariat Edisi 4 dengan Program SPSS BP Unversitas Diponegoro. Semarang.

Kenny, K. 1996. What Is Effective Training?, Human Rights NGO Capacity-Building Programme - Iraq.

Makokha, A. and Ongwae, M. 2007. 14 Days Teaching Metodology Course Trainer Handbook, German Develovment Service Kenya (DED).

Marpaung, dan S.A. Giri. 2003. Komunikasi dan Presentasi Efektif dalam Pengajaran, Bahan Ajar Kewidyaiswaraan Berjenjang Tingkat Pertama Lembaga Administrasi Negara Republik Indonesia. Jakarta.

Moeheriono. 2010. Pengukuran Kinerja Berbasis Kompetensi Competency Based Human Resource Management, Ghalia Indonesia. Bogor.

Rana, K, and A. Immink . 2007. Trends in Global Aquaculture Production:1984-1996. Fishery Information, Data and Statistics Service (FIDI). 
Rendall, R. 2004. Facing an Ageing Workforce: Information for Public Service HR Managers Strategic Development Branch. State Services Commission.

Shahril. 2008. The Influence Of Knowledge Shering On Motivation To Transfer Training: A Malaysian Public Sector Context School of Management. Faculty of Business and Law Victoria University Melbourne. Australia (Disertasi)

Sugiono, 2002. Statistik untuk Penelitian, Alfabeta, Bandung.
Waluyo, M, 2011. Panduan dan Aplikasi Struktural Equation Modelling (Untuk Aplikasi Model dalam Penelitian Teknik Industri, Psikiologi, Sosial dan manajemen), PT Indek. Jakarta.

World Health Organization . 2001. Men Ageing And Health Achieving health across the life span Noncommunicable Diseases and Mental Health Cluster Noncommunicable disease prevention and Health Promotion. Department Ageing and Life Course Unit. Geneva. 